\title{
Popular Protests, the Public Sphere and Court Catholicism. The Insults to the Chapel of the Spanish Embassy in London, 1685-1688
}

\author{
Cristina Bravo Lozano \\ Universidad Pablo de Olavide. Departamento de Geografía, Historia y Filosofía. Ctra. Utrera km. 1, 41013 Sevilla \\ e-mail: cbraloz@upo.es \\ ORCID iD: http://orcid.org/0000-0001-9919-1270
}

Submitted: 30 October 2016. Accepted: 4 March 2017

\begin{abstract}
The coronation of James II, a Catholic, brought about a profound political change in religious matters in the British Isles. At court, a Catholicizing process was introduced, supported by the monarch and the European diplomats who opened chapels in different parts of the city. However, this missionary effort had an unequal reception and caused a popular rejection against this new religious culture, leading to demonstrations of a markedly confessional nature. The chapel of the Spanish Embassy suffered the insults of the crowd on two occasions: the main consequence of these altercations was its destruction during the revolution of 1688. Although, superficially, this protest movement can be interpreted as anti-Catholic, it must be understood in a political context. With each new royal ruling, the protests gained strength until finally exploding after the flight of the King to France. This paper focuses on the popular protests and the explicit remonstrance of English Protestants against these Catholic altars and places of worship, with particular emphasis on the residence of Pedro Ronquillo. This study looks at popular protests and the reaction of the authorities, perceptions of the English and the use of the public sphere, the reception and dissemination of news and the impact of popular religious violence on foreign affairs in this crucial phase of English and European history.
\end{abstract}

KEYWORDS: Chapels; Diplomacy; Protests; Disorder; James II; Pedro Ronquillo; Spain; London.

Citation / Cómo citar este artículo: Bravo Lozano, Cristina (2017) "Popular Protests, the Public Sphere and Court Catholicism. The Insults to the Chapel of the Spanish Embassy in London, 1685-1688". Culture \& History Digital Journal, 6 (1): e007. doi: http://dx.doi.org/10.3989/chdj.2017.007.

RESUMEN: Protestas Populares, Esfera Pública y Catolicismo de la Corte. Los insultos a la capilla de la Embajada de España en Londres, 1685-1688.- La coronación del católico Jacobo II provocó un profundo cambio en la política religiosa de las Islas Británicas. En la corte se inició un proceso de catolización, respaldado por el rey y los embajadores europeos, los cuales abrieron capillas en diferentes partes de la ciudad. Sin embargo, el esfuerzo misionero fue interpretado negativamente fuera de la corte, causando un rechazo popular contra la nueva cultura religiosa que, a su vez, generó muestras de protesta de carácter confesional. La capilla de la embajada de España sufrió el insulto de la multitud en dos ocasiones: la principal consecuencia de estas alteraciones fue su destrucción durante la revolución de 1688. Pese a que en la superficie este movimiento de protesta puede ser interpretado como anti-católico, debe ser puesto en relación con el contexto político del que emanaba. Con cada nueva medida adoptada por el rey, las protestas fueron adquiriendo más fuerza, hasta explotar tras la huida del rey a Francia. Este texto se centra en las protestas populares y las reacciones de las autoridades, las percepciones y uso de los ingleses de la esfera pública, la recepción y diseminación de noticias y el impacto de la violencia religiosa popular en las relaciones exteriores durante esta etapa crucial de la historia de Inglaterra y Europa.

PALABRAS CLAVE: Capillas; Diplomacia; Protesta; Desorden; Jacobo II; Pedro Ronquillo; Monarquía de España; Londres.

Copyright: (C) 2017 CSIC. This is an open-access article distributed under the terms of the Creative Commons Attribution License (CC BY) Spain 3.0. 
The accession of the Catholic James II to the throne of England seemed to herald winds of religious change for the subjects of his kingdoms. The Count of Castlemaine was sent to Rome as extraordinary ambassador to reestablish relations with the Papacy. Ferdinando d'Adda, a Lombard count, doctor in laws and nephew of the Prince Livio Odescalchi, arrived in London as a pontifical agent. He was later formally appointed as a nuncio (Bravo Lozano, 2016). Despite these courtesies, relations with Innocent XI were never cordial. The political decisions taken by the new sovereign sought to favor Catholics, and new chapels were opened in London, including one in Whitehall. However, not all the members of Parliament appeared to be supportive of this new policy of religious tolerance, which was aimed at imposing royal beliefs across his territories according to a particular style of Bourbon Gallicanism (Mi1ler, 2008: 229). The population at large, moreover, showed little enthusiasm for it. In a milieu where the popular feeling and, above all, the mass rejection of a program and political pressure heavily influenced the religious policies of the crown, the king encountered new problems in the development of an authoritarian monarchy. His cabinet, made up purely of gentlemen sympathetic to the sovereign's faith and by members of Society of Jesus, tried to limit the scope of action of the Privy Council, while simultaneously the Roman religion was consolidated as a key factor in the political system at all levels, from the royal household to the army (Jones, 1991).

The 1688 Revolution must be understood in the context of the nation-wide expression of disgust and protest described by foreign diplomats. This having been said, these sources demonstrate that the Jacobite regime was relatively robust, and was certainly capable of controlling the crowds and limiting their scope of action (Walter, 2007). Still, the breadth and vehemence of the dissent demonstrates a profound desire for change which supports the argument by Steve Pincus that if the regime was well entrenched then the movement to overthrow it was deeply rooted in English society and culture (Pincus, 2013). Yet while there were protests, skirmishes and insults aplenty, there was not a mass popular movement that constituted an existential threat to the regime. Law and order was essentially maintained and for this reason the overthrow of James II must fundamentally be attributed to his loss of nerve and decision to flee in December 1688 .

In this context of mounting political and confessional tensions, the Lombard protestant Giovanni Arconati Lamberti, who signed his papers as Gregorio Leti (Álvarez-Ossorio Alvariño, 2001: 169), provided a detailed description of the public chapel of the Spanish ambassador Pedro Ronquillo. According to the account contained in Il ceremoniale historico e politico, the success of this confessional space was due to its correct organization, the use of visual elements as tools of confessional persuasion and the strict prevention of political interference in religious matters. Thus, 'as this lord naturally loves pomp and ceremony, and to appear to be someone who does pomp and ceremony, and so he is not content to do things with moderation. For this reason while still trying to understand the nature of the kingdom and its weather, he wanted to have for himself the glory of a chapel served as if it was a Cathedral in a Catholic country. Thus he had set up his chapel in the garden and the courtyard. While the door of the chapel was opened, those who were in the courtyard knelt as they were in church in front of the altar where the priest consecrated the Eucharist'.

Recognizing the effort of the royal ministers to consolidate his chapel as an attractive emblem of Catholicism, Leti had no compunction about criticizing such a mechanical attempt at proselytizing, which he saw as alien to the customs and manners of the Stuart court and the practices of other ambassadors, such as the French representative. In this way the words of the Milanese convert in 1685 spoke of a reality that Ronquillo would describe and reflect upon in the subsequent years. It was not the first time that the Catholic chapels of public ministers resulted in political controversies (Raleigh Trimble, 1946; Kaplan, 2002). It touched on the transmutation of the Baroque Spanish religiosity in reformed lands, a cultural shock of grave repercussions for the missionary program sponsored by Madrid (Leti, 1685: 671-672).

\section{CATHOLICIZING THE LONDON COURT}

In 1671, during his second embassy, the Spanish Count of Molina observed that the arrival of an angry mob was an occasional event, one that usually occurred on feast days, '[the rabble] are undeterred by the prison time they repeatedly face or by the maltreatment they suffer at the hands of the royal guards'. ${ }^{1}$ The origins of this popular resistance to royal policy were fundamentally grounded in confessional factors. Under the reign of James II these expressions of religious discontent greatly grew in strength and came to acquire distinct connotations of political opposition. More frequently than in the previous period, the steady growth of incidents focused on - or, more accurately, against - centers of Catholic worship came to exhibit near-endemic characteristics and was spread throughout England (Miller, 2008: 257-259).

From 1686 London saw a proliferation of places of Catholic worship, a change supported by the British crown in an attempt to return the kingdom to allegiance to Rome while allowing the Protestants, who of course constituted the vast majority of the population, to continue to worship in peace (Ibidem: 239-249). ${ }^{2}$ These innovations introduced by the Stuart monarch, with the construction of a new royal chapel, caused a profound dynamic that increased the number of places of devotion within the urban panorama (Macaulay, 1858, II: 99-100; Pincus, 2013: 288-289). ${ }^{3}$ With royal backing, and the 1687 decision of the General Assembly of the secular English clergy to provide an incentive for the establishment of chapels across the country, the Catholic regular Orders started to become much more visible in public through the building 
of their altars (Pincus, 2013: 288). ${ }^{4}$ Thus, the Discalced Carmelites established a church 'in the middle of the city', in Bucklersbury. ${ }^{5}$ In contrast, the English Benedictine fray Maurus Corker, representative of the Elector of Colonia, preferred some distance from the urban centre, setting up his chapel in the suburbs, in Saint John's Clerkenwell. ${ }^{6}$ In addition, two chapels were established in the area of Somerset House and Lincoln's Inn Fields: one was opened by the Dominicans and one by the Franciscans. $^{7}$

At this juncture the Jesuits, firmly committed to the Jacobite regime and wielding considerable influence in its political program, saw the chance to carry out their longstanding desire of founding and running their own college in England. Making use of the old Savoy hospital, a strategic position near to the Queen Dowager and surrounded by soldiers, they established a house under royal patronage and according to the Grammar school model (Macaulay, 1858, II: 98-99; Holt, 1990: 21-27). Jesuit classrooms welcomed more than 200 English students devoted to the study of Letters. Remarkably amongst their numbers were some 70 Protestant pupils who attended on account of the quality of teachers and who wore secular clothes (Whitehead, 2009: 131-146, in particular, 135137).

The educational purposes of these institutions went beyond the differences of creed because the Jesuits offered 'the students who were not Catholic that they should not have to perform any act that runs contrary to their religion'. Under this unique form of tolerance and theoretical permissiveness, the Jesuits did not renounce their missionary vocation. Ronquillo believed in the value of this establishment 'to advance one doctrine and the catechism' ${ }^{8}$ With the aim of eventually persuading their Protestant students to take the path of the True Faith, the spirit of their teaching was informed by the mission that the Society had sought to cultivate in the kingdom for almost a century (Carrafiello, 1994; McCoog, 1996, 2012; Walsham, 2003). In this way the process did not depend upon imposing ideas and doctrine on the students, but rather upon an evangelical rhetoric extolling the value of humanistic learning. Moreover this pedagogical approach also made it easier for those who might want to follow the precepts of Ignatius Loyola to do so. ${ }^{9}$

Some days after his arrival at the British court, at the end of 1685, Ferdinando d'Adda expressed his intention to build a chapel as soon as he could assume publicly the status of pontifical minister. Innocent XI ordered Adda, officially recognized as the envoy of the Pope the following March,

\footnotetext{
'that you should open a chapel with the greatest decorum that can be achieved, establishing it with the number of chaplains that is needed and in line with the example of the other Catholic representatives who have their own chapels for the practice of religion'. ${ }^{10}$
}

In order to carry out these orders, the envoy took a house near the court, in Saint James's Park, with a spa- cious room to establish a chapel of proportions fitting to his office of apostolic legation. ${ }^{11}$ Aiming to avoid the sort of 'frights' that the mobs were affording the agent from the Palatine (see below), he recruited men of exemplary lifestyle and four chaplains of established virtue for his household. His main consideration in this measure was that, as a missive from Rome had warned him, 'it will forever be observed with critical eyes this kind of buildings'. ${ }^{12}$ On the morning of Pentecost Day 1686, the first mass was celebrated in the nuncio's chapel, followed by another three more due to the assistance of faithful and the calm of this festive day. ${ }^{13}$

At the same time as the chapel of the nuncio was being set up, another place of worship was being established. This was under the protection of the English Catholic James Stanford, the representative of the Elector Palatine and Duke of Neuburg. It was constructed on the orders of the King in a house on Lime Street, at some distance to the other chapels, and was cast as a devotional complex for Catholics merchants. ${ }^{14}$ In one of his letters, Pedro Ronquillo reflected on the rumours of the concerns and fears that started to circulate in the city in the light of this royal order, mentioning that the impact might explain why its establishment brought about a gale of insults and slander (Macdonald, 1927). ${ }^{15}$

From the very moment when the work began, in February of 1686, the chapel seemed condemned to suffer the affronts and injuries of the crowd, which was particularly hostile to the establishment due to its construction being overseen by a native of obscure social origin, whose authority they did not recognize and who, moreover, served as minister to a foreign Prince (Rowlands, 1999: 70). ${ }^{16}$ Among the first disorders was the breaking of some furniture; construction workers were intimidated, thus providing Stanford with a harbinger of the troubles that might arise. ${ }^{17}$ Some days later the Mayor of London was persuaded to intervene against this new project by an influential group comprised of the bishop of London Henry Compton, the dean of Saint Paul's William Sherlock, the gentleman Robert Clayton and others of this 'type'. He commanded the workers to stop their work, thus overriding the royal order on the sole authority of his office of mayor. ${ }^{18}$ This intervention, and the subsequent delay, avoided infringing upon the representative from the Palatine's diplomatic immunity on the grounds that his exemptions or privileges could not be applied to a house where he did not live yet. ${ }^{19}$

Stanford's complaint about this unwanted intervention led the mayor to have to explain himself to James II and the Privy Council, while the sovereign ordered to resume the construction in the meantime. In addition to demanding an apology from the mayor, the King and the Lord Chancellor George Jeffreys reprehended him for his indiscretion and unilateral action against a foreign minister. They reminded him how matters of this sort were not dependent upon his jurisdiction and that 'none of those of England can take action but rather should give an account [of the issues] to his Majesty or to the Secretary of State'. In addition, they also suggested to him that, in the future, 
'you should not allow yourself to be deceived by the advice of churchmen, nor by the badly intentioned'. He should take care to avoid any scandal related to this chapel (Ellis, 1829, I: 83-84). ${ }^{20}$

Despite the royal warning, the cacophony did not stop. In his correspondence with the Marquis of Villagarcía, the Spanish ambassador in Venice, Ronquillo played down the impact of the first actions of the crowd. He considered them a temporary phenomenon that, confined to festive days, 'will be forgotten with time and will diminish little by little'. ${ }^{21}$ Yet the passage of time led the English to become more agitated and the ambassador's assessments tended to underline the need for precaution before 'some emotion' came from this sense of resentment. ${ }^{22}$ Thus when, on Easter Sunday, the chapel of Stanford opened its doors, the agitators, who had manoeuvred themselves to try to avoid precisely this outcome, entered into the chapel where the Mass was being said with their hats on. This scandalous act, so demonstrative of their religious and cultural resistance to the programme of the crown, led to the arrest of 30 men as an example to the general public (Ellis, 1829, I: 111-112; Miller, 2008: 246247). ${ }^{23}$ The application of justice was not enough to calm down their bad temper. In this tense environment, a riot of ten thousand apprentices at the beginning of June was staged on the outskirts of London, having been carefully planned by its organisers, 'with one part having a rose on it and another the image of a fox as an enigma and sign of the union'. ${ }^{24}$ The protesters were armed with a range of weapons, including some lead ones, and 'a certain disposition to use them to wound and injure without making much noise'. They plotted to demolish the chapel of Lime Street. $^{25}$

The disorders were growing in intensity. These altercations focused on the doors of the chapels, where threats were made and shouts contrary to Catholic religion could be heard.$^{26}$ The ridiculing of Roman devotional practices led the protesters to throw stones and oranges at altars. They also made crosses of mud in the middle of the street, took dirty water from puddles and sprinkled it about in mocking imitation of the Catholic ritual, or hung a dead cat on the door of Stanford's chapel 'and above it, a certificate that all Catholics were asked to pray to God for the soul of this feline' (Ellis, 1829, I: 118-119). ${ }^{27}$

Although he identified acts of this sort as insolence rather than anything more serious, and noted that the authorities did not really deal with the miscreants with the exemplarity that some demanded, Felipe de la Guerra observed that the popular movements encompassed the chapel like a hydra 'and where one head is cut off, another seven appear'. ${ }^{28}$ These altercations, which reached a crescendo on the evening of 18 September 1686 in the Wild House of Pedro Ronquillo, were spreading across the kingdom. Mobs in Bristol, Worcester and Coventry gathered to show 'that they were not less than those of London in agreeing to a chapel', causing disturbances of different importance and impact. ${ }^{29}$ As in the court, the attempt to humiliate Catholic practices was manifested in scandalous depiction of the Pope or a procession of the
Holy Eucharist shouting 'you see here the infamous God of the papists. Long live James II and may the papists die!' 30

\section{'IT WERE BETTER THAT BUDA WAS IN THE HANDS OF THE TURKS THAN THE PAPISTS'}

On 11 September 1686 Ronquillo transmitted the news of the taking of Buda to James II, who at this moment had moved his court to Windsor (The celebrations in London for the taking of Buda and its comparative with those developed in Madrid are exposed in Bravo Lozano, 2015). By means of a general assault, the allied Christian troops had recovered the old capital of Hungary from the Ottoman Turkish Empire. News of this event, in which English soldiers - most notably James Fitz-James, the illegitimate son of the King - had participated, occasioned happiness in the royal palace (Vivo, 2012). ${ }^{31}$ Indeed James II's celebration of this triumph was not very different from that of the Emperor Leopold I himself. ${ }^{32}$

The news dominated courtly conversations during the following days. In addition to congratulating the nuncio Adda for this triumph of Christendom, the King invited representatives of European princes and other distinguished gentlemen to dine at his table. ${ }^{33}$ Although only discrete festivities were performed due to the limitations of the palace, a number of different celebrations began to be planned for after the monarch's return to London. On Sunday 22, a ceremony of thanksgiving would be celebrated in the Royal Chapel of Saint James and the three main churches of the city: St Peter's of Westminster, St George's in Windsor and St Mary-le-Bow Church. ${ }^{34}$ Aiming to strengthen his religious politics, James II prepared celebrations in line with continental festive models. On the day in question the Catholic bishop John Leyburn, Apostolic vicar of England, celebrated a mass before the majesties, ministers and courtiers, and afterwards a $T e$ Deum was sung. ${ }^{35}$ In addition the king ordered the composition of sermons and individual prayers, as A form of prayer and thanksgiving to Almighty God for the prosperity of the Christian arms against the Turks, and especially for taking the city of Buda, penned by the bishops of Durham and Rochester. ${ }^{36}$ In order to give it greater dissemination, this work was printed as a chapbook and subsequently hawked and sold on the streets of London. ${ }^{37}$

Pedro Ronquillo thought that the basic function of this act was historical, noting that for more than one-and-ahalf centuries this hymn had not been intoned in England, nor had a religious ritual of this nature been celebrated there in this timeframe. ${ }^{38}$ The popular reception of this news and the 'indescribable satisfaction' that reports of the battle of Buda elicited in the public caused him a certain degree of surprise. As in previous occasions, several curious Protestants followed 'the high spirits with which the good Christians and Catholics celebrate this triumph'. ${ }^{39}$ Others, described as fanatics by the diplomat, did not appear as favourably inclined towards the religious feasts and public demonstrations. The Jews, incidentally, took no part in these celebrations. ${ }^{40}$ Expression 
of this anti-Habsburg or anti-Catholic sentiment came in riots, the tearing up of leaflets and the 'mistreatment' of the sellers of the small prayer book then being sold. ${ }^{41}$ This cultural resistance took concrete form in an insult to the chapel of the Spanish embassy.

Motivated to strengthen his image as an orthodox king, James II requested of the European diplomatic representatives that they celebrate the Christian triumph in their chapels. Ronquillo tried to exalt the role played by both Carlos II of Spain and the House of Austria through his words and actions at court. Although in Windsor he did perform some modest demonstrations of respect and congratulations, the parties that were held in the Wild House had more sumptuousness and ostentation 'as they that have exceeded that of any other'. ${ }^{42}$

With a great number of means, he organized three days of festivities 'in the most solemn form that can be done in Rome': a number of masses would be sung with 'music coming from both voices and instruments', a Te Deum would be sang and the Holy Sacrament -symbol of the Habsburgs' Pietas Eucharistica - would be exhibited. The final day would be reserved to honour the souls that had fallen in the taking of Buda, among them some conspicuous Spanish aristocrats..$^{43}$ Wednesday 18 was the day chosen by Ronquillo and nuncio Adda to celebrate this allied success in their respective chapels. In the evening, and according to the tradition, their houses were lit up completely with torches in the windows of the main façade, fireworks were set off in the street and bonfires lit. ${ }^{44}$

These ceremonies began in the Spanish embassy with a banquet for fifty English gentlemen and ladies of court, including the sub-secretary of State and secretary of the Privy Council, William Bridgeman ${ }^{45}$. The liberality of the minister was extended to common Londoners by the placing of four barrels of wine in the doorway of his house ${ }^{46}$. From different windows, the guests enjoyed a splendid pyrotechnic display that the minister had carefully planned. However, "just over an hour after having lit [the fireworks], they [the protesters] suddenly began to throw stones from the street' (Harris (1997: 133). ${ }^{47}$

The explosion of the device was drowned out by the noise of the insults. The apprentices took the barrels of wine and destroyed the firework machines. They continued to scatter embers and throw blunt objects and stones while shouting 'It were better that Buda was in the hands of the Turks than the papists' ${ }^{48}$ The disturbance acquired such dimension that the royal guard had to intercede, although by the time the soldiers arrived the mob had already dispersed. ${ }^{49}$ The incident was not over, the houses did not burn and only material damage was sustained, with broken window panes and the stained glasses of the chapel being smashed. ${ }^{50}$

This use of violence against a supposedly immune space such as the Wild House is included in the continuum experienced by the envoy from the Palatine. It constituted a grave diplomatic insult and an offence against the representative of the king of Spain. The following day, Ronquillo lit new bonfires under the protection of the royal guard. This repetition of the festivities allowed the minister to be compensated and he himself considered it satisfaction enough for the excesses committed against his privileges on the previous night. ${ }^{51}$

It may have been accidental that these altercations only happened near the Spanish embassy, and not near that of the nuncio Adda. However, the incident offers a more profound insight into how the sumptuousness of Spanish religiosity caused a concomitant Protestant rejection. The mob expressed their anti-Catholic sentiments and opposition to such public demonstrations of an overtly religious nature in terms that were more violent than those seen up until this juncture. ${ }^{52}$ Although, the ambassador notified Madrid of the incident, it did not bring about any change in Anglo-Spanish relations. The minister only called for punishment to be handed out to the 30 apprentices arrested that night. James II acceded to this petition, but it was not applied with vigor sufficient to make it exemplary to other protesters, actual or potential. $^{53}$

The guilty parties in fact left prison unpunished after passing just a few days behind bars. This arbitrariness in the methods of punishment shocked the other European representatives. The ius gentium showed itself vulnerable and in London there was no legislation that referred to the altercations and attacks on the embassies, first that of Neuburg, and then the Spanish residence. ${ }^{54}$

\section{A REPRESENTATION IN RUINS. THE CHAPEL, TUMULTUOUS STAGE OF THE 1688 REVOLUTION}

Through 1687 the atmosphere continued to be strained, particularly after the passage of a bill offering freedom of religious conscience. Every Sunday a new 'party' was organised for the crowd. The efforts of the mayor and his magistrates did not contain the surge of popular violence that was experienced in London. Throughout the that summer the blood continued to flow while the mob gathered to knock down a Catholic house. Having tried to disperse them with warnings such as 'they will be fired upon with shot' and orders not to persist in their actions and to move off and cease their protests, a company of infantry opened fire, 'they gave them a spraying' that killed several protesters and wounded others. Yet the persistence of this problem, together with the more virulent aspect of these events, made it difficult to predict what would be the direction of a course of events which the authorities appeared unable to control. ${ }^{55}$

The context to these actions was the latent anti-Catholic element within English culture. However, it might be wrong to dismiss the political factor and the government ambitions of James II as ways of understanding these protests, as the monarch's authoritarianism was awaking fierce resistance, sometimes on account of the perceived influence of French Gallicanism and, at other moments, because of the presence of Jesuits in his immediate circle (Pincus, 2006). ${ }^{56}$ In the light of the establishment of Catholic chapels that allowed the nuncio Adda to say of London that 'it already appears a Catholic city', the din 
against altars across England during the Jacobite reign began to sound more like cannon fire. The origin of these dissonant rhythms was a discontent crowd, 'although the leading people are sorry for this, they do more to ensure that they do not risk their quiet than to approve the resolutions' ${ }^{57}$ The passive obedience of elites and the disagreement of Englishmen of low social condition revealed the delicate situation that affected Catholicism in the British court. The divergence of elements of political and religious opposition, as well as its regular expression in the deterioration of popular non-conformism, heralded an attack upon them and even the generalized destruction of all the Catholic chapels thrown up during the Jacobite reign. This was to occur during the revolutionary crash of 1688.

The succession of critics willing to speak up against the authority of the monarch on the grounds of his controversial confessional policy articulated a general political opinion prevalent among reformers. It aimed to safeguard the interests of the various political and religious communities. From the parliamentarian elites to ministers speaking from Anglican and Presbyterian pulpits, a common theme was the restoration of the kingdom and its constitutions according to the parameters previous to 1685 . The dissenters were gaining strength and needed only a figurehead capable of defending their opposition to the king. The chosen individual was James II's own son-in-law: the stadholder of Holland, William of Orange. ${ }^{58}$ Invited by the high clergy of the Church of England and a section of the peerage to come to England, the prince accepted the proposal and organized a military expedition with the full support the General States, who saw an opportunity to thwart French ambitions (Hoppit, 2000: 15-19; Troost, 2005: 191-194; Levillain, 2010: 353-364). Thus, he revealed in his dynastic allegation how

\footnotetext{
'the aim of this expedition is nothing other than to gather a free and legal Parliament, with the aim that the two chambers can agree to establish such laws as are right for the security of the Protestant religion and unite the Anglican church and the other non-conformists, and so secure for all those who want to live peacefully beneath a government that belongs to good subjects, without excluding even the papists themselves'. ${ }^{59}$
}

The stadholder reaffirmed his determination with his allies, among them Carlos II. Given the difficulties and discord between the Stuart King and his subjects, which were near to a formal rupture, William went to England to answer the petitions of leading English individuals that the old political balances be reestablished. Apart from justifying the presence of his large army, he explained in this declaration of intentions how his objectives included not hurting the reigning monarch and his successor, the newborn James Stuart. Nor was his plan to destroy Catholicism (Herrero Sánchez, 2002: 418). His aims would focus on the public good, trying to remedy the disorders and irregularities that had been committed against the laws of this kingdom by the bad advice of the badly-in- tentioned' in order to restore the link between king and kingdom, ruler and ruled.

Pedro Ronquillo observed how the behavior of those supporters of change was grounded in both their political interests and private ambitions. The grander proposals and justifications of Orange about the equilibrium between authorities were not really as significant. However, the minister also expressed his doubts on the Dutch claims about the legitimacy of the Prince of Walles, in life of James II, because 'this same reason and the obstinacy of the prince [William], I fear that they will not return to reasonable behaviour and will instead come to blows' ${ }^{60}$

The political climate in the Stuart court and the illomens perceived by Ronquillo heralded the storm that was gathering in October and was shortly to strike the British coasts: it is best known in to history as the Glorious Revolution (Speck, 1989; Hoak and Feingold, 1996; Miller, 1997; Israel, 2003; Pincus, 2013; Harris and Taylor, 2013; on the expression, see Niggemann, 2012). Particularly critical of the Jacobite government, the Carolinian legate pointed out how the royal cause was in grave danger due to the influence of friars and clerics in the political direction of the kingdom. The Spanish ambassador, dismissing them as ignorant and moved by their private interests, reflected that 'perhaps they will have more good fortune living with noise than peace', with the arrival of William of Orange. ${ }^{61}$ This royal intervention and the way that the government was adopting the French style was preparing the land for the revolution that lay two years ahead, being manifested in the crowd and their slanders and insults against the chapels. Although the fuse burnt down and things exploded on 11 December 1688, the gunpowder was preparing some weeks before.

On Sunday 18 October, the chapel of the Palatine envoy Stanford saw a grave disorder on the occasion of a sermon preached by the brother of the Jesuit Edward Petre, one of the principal advisers of James II. According to the testimony of the nuncio Adda, the scandal occurred during the homily, when this preacher spouted dogma about how 'the sacred scripture in the time of Elizabeth, whose name is venerated here, was falsified' for the Protestants. This controversial claim, made public in a pulpit whose very existence was the cause of considerable debate, was rejected with insults by a 'reformed man', who was hidden among the Catholic faithful (Campana de Cavelli, 1871: 290). ${ }^{62}$ Shortly another violent crowd was gathering and the level of protest rising, being encouraged by the 'hatred in which the name of Petre is held', due to the control wielded by this father over the royal persons (Ellis, 1829, II: 269). ${ }^{63}$ The mayor having extinguished the initial uproar, the atmosphere remained marked by discontent to the extent that in the evening another grave insult was made against one Discalced Carmelite friar, who was shaken on leaving his chapel in Bucklesbury (Lamberty, 1702, I: 325). ${ }^{64}$

The commotion caused by these incidents and the advance of William of Orange put the sovereign in a complicated situation. His reduced forces had to try to control the troubled English and, in turn, oppose the army of the 
Dutch stadholder. Therefore, his first intention was to soothe the popular spirits with the objective of focusing all his efforts and available resources against the menaces that was close to the court. With this strategy, and suspecting the reaction of his subjects, James II entrusted the care of the city to the magistrates, while he tried to win over some of the Protestant bishops who had been defendants against his cause, guaranteed them the protection of their religion in return for their controlling the people with their homilies 'on this security' (Miller, 2000: 200-201). ${ }^{65}$

This attempt to control the multitude through the sermons of the highest ecclesiastical authorities did not reduce the pressure exerted by the actions of the crowd, nor did it serve to redirect its aims (Sachse, 1964). At the beginning of November, the clamour felt on Sunday in some places of the kingdom - especially in the suburbs of London. Thus, the Jesuits reduced their activities in the Stanford chapel to the 'duration of two masses'. ${ }^{66}$ The offices and sermons were also moderated in the Carmelite chapel on account of the fear felt by many Catholics. In their whimsical attempt to return to previous practices, these regulars found such number of 'youngsters' who were present in such numbers that it required three companies of urban militia to subdue them. They "were ready to consign it to the flames and would have burnt the chapel to the ground were it not for the danger of setting fire to the adjoining houses'. ${ }^{67}$ The state in which the chapel found itself after this ransacking, with its liturgical ornaments stripped away and various additional forms of damage, compelled the other religious orders to cease their activities for fear of suffering similar attacks. It also caused Ronquillo to take care not to put his own chapel at risk and face another predicament similar to that of $1686 .{ }^{68}$

There were mounting royal fears in the days preceding a pivotal commemoration-the anniversary of the Gunpowder Plot (1604). However the day of 15 November actually passed off in relative peace. This having been said, on the evening of 14 November, a rabble gathered in Lincoln's Inn Fields with the apparent aim of attacking or insulting the Franciscan chapel. ${ }^{69}$ Ten days later, on a Sunday, the Benedictine house and chapel belonging to Father Corker (the representative of the deceased Elector of Colonia) faced an incident. A multitude of 'young craftsmen' arrived, apparently intending to reduce it to rubble: this attack failed only because of the arrival of royal militias. The following morning more than one thousand apprentices ransacked the convent, loading a cart with looted pieces of furniture and other basic tools, before proceeding to burn these possessions in the middle of the square. One person was killed and others were wounded during the charges by the guards who tried to prevent this attack.

Aware of the number of simultaneous violent incidents, James II reinforced security in London with a Scottish battalion deployed to wander the streets and given licence to fire on the crowds if necessary. ${ }^{70}$ The festivities in honour of the memory of Elizabeth I ( 27 November) were therefore celebrated in a climate of political and re- ligious tension for the Stuart crown. The anti-Catholic element was, of course, central to the commemoration of days of this sort, and was usually expressed in the burning of an effigy of the Pope. This act represented an explicit representation of the historically decisive role of Elizabeth, England's Protestant Virgin Queen. However, in 1688 the innovation during the commemorations was expected to coincide with the demolition of all the new places of worship that 'there are against the law, as the people say', meaning, those founded in the three previous years and deeply unpopular with many Englishmen.

In addition to the military reinforcements, the monarch took precautions to control public spaces, hoping to prevent the venting of popular fury in this way. Thus, he asked the Bishop of Leyburn, apostolic vicar, "that he should give an order to the prelates that they close their chapels, and withdraw the priests and the furniture from them'. Given the threat of destruction and harassment, the Jesuits anticipated the royal orders and abandoned their institute, taking their possessions with them. The Franciscan did the same, moving their persons and treasures to the nearby Wild House, the residence of Ronquillo. ${ }^{71}$ Despite the calm in which the festivities subsequently took place, the chapels remained closed during the royal sojourn in Windsor, with their clergy seeking to avoid the dangers that stalked them. In the midst of this degree of adversity, when Catholic acts of devotion continued only in the royal chapels and those of the foreign diplomats, the Spanish embassy became a point of refuge for a great many Catholic churchmen. His claims to diplomatic immunity and the district in which his house was located, meant that he could convert it into a religious centre not only for faithful, but also for priests. Thus becoming a physical representation of Spanish confessional politics and policies, Ronquillo increased the amount of space available to the chapel, adding a third altar where all 'priests who came there' could celebrate the liturgy because 'in addition to freeing themselves from risk, they take advantage of this title to avoid any harm to their persons'. ${ }^{72}$

On 11 December 1688, the night sky of London was once again lit up in an extraordinary way. So great was the spectacle that it reminded some of the great fire that devastated half city just over twenty two years previously (Miller, 2000: 205). That night the places of Catholic worship burnt, but the flames also consumed a period of English history. The discontent and the chaos caused by the flight of James II to Saint-Germain-en-Laye proved a trigger to popular protests. They had waited expectantly for circumstances such as these, because 'in the absence of the king, the law and government are also missing' (Miller, 2000: 200-209; Troost, 2005: 203-207). ${ }^{73}$ The propensity of this popular uprising to finish with any vestige or memory that a Catholic King had recently sat upon its throne can be interpreted as a damnatio memorice with which to forget the years of Jacobite authoritarianism.

This idea of changing the English political landscape was translated into a revolutionary movement through a general clamour of complaint and the destruction of the 
buildings associated with the fleeting reign. This outbreak of political violence, shaped by religious sentiment, was expressed in numerous altercations which constituted a dramatic break with what had gone before. The recently founded chapels once again became the main target of uncontrolled attacks. These buildings represented the shift from the dissimulated Catholicism and practical tolerance of the reign of Charles II to the strengthening and projection of public celebrations of an explicitly Catholic nature and chimed professions of faith under James II. Thus, one after another the altars of regular orders, the 'impregnable' chapels of European ministers and the Royal Chapel of Saint James were despoiled and burned. ${ }^{74}$ Only the chapel of the Queen Dowager in the palace of Somerset House escaped the flames, while the Savoy school closed and Catholics and Jesuits had to avoid public appearances. ${ }^{75}$

Favoured by the confusion at court after the royal flight, different points of the city ignited. With little or no order or public control, the mob first made an appearance near the Guildhall and Lincoln's Inn Fields, where more than twenty thousand people congregated (Pincus, 2013: 445-446). According to the accounts and testimonies of European representatives, both witnesses and victims of this attack, it began with the demolition of the Franciscan chapel, the ruins of which were immediately set alight. Moving through the streets, and brandishing the possessions of the Catholic buildings in triumph, the crowd carried oranges stuck in swords and stakes as a representation of their political ideology and their inclination to the Prince of Orange (Ellis, 1829, II: 350).

Due to its geographical setting, Ronquillo's chapel was to witness the most tumultuous expressions of popular violence. As the smoke drew closer, the ambassador had no confidence in the protection afforded him as a foreign diplomat, and so asked the Count of Craven to send troops to guard Wild House. Craven was initially cautions, and it was not until after a second petition made to the General Blair Worden that the London militias arrived in the vicinity of Wild Street. With time only to save his life, the ambassador and his family escaped from the shouts and insults through the rear garden. Those soldiers sent to protect the residence, 'only served to help to rob it and burn it and the chapel down, the plebs having previously done the same with such enthusiasm that nothing was left but the foundations' (Maura Gamazo, 1951, I: 33). ${ }^{76}$

The unconstrained mob forced the doors and looted all the silver from the Royal Chapel, seizing jewels and other treasures. Amongst these were liturgical ornaments and monies those Franciscan friars and other prominent Catholic supporters of James II deposited inside it as safeguard, thinking that these were secured spaces, being highly protected and benefiting from diplomatic immunity. Their plundering and demolition were not the only atrocities committed in these days, with one report stating that the mob piled up in the street 'everything that they did not want to steal and which could be set alight', including coaches, official documents and files and a rare library (Rodríguez Villa, 1875: 308-309; Pincus, 2013: 446; Ochoa Brun, 2006, VIII: 122; Powell, 1988: 205; Campana de Cavelli, 1871: 421-422). ${ }^{77}$

The same misfortune overcame the chapel of the Florentine abbot Francesco Terriesi, victim of three successive assaults. Yet having previously been warned, the agent had time enough to abandon his house in Haymarket with the help of his neighbors, to whom he donated several rich tapestries and paintings that had previously decorated his room and chapel. Simultaneously, another fire took root in the Benedictine chapel belonging to the ambassador of the Elector of Colonia in St John's Clerkenwell. At the same time, the chapel of the Palatine envoy James Stanford in Lime Street, the traditional centre of English religious and cultural resistance, was razed to the ground. The Carmelite convent of Bucklersbury was also destroyed, as was the printing house of the royal printer Henry Hill in Blackfriars. Thus the centre for the diffusion of Catholic works and royal sermons was silenced suddenly with the destruction of its press by the flames that fed on the books stored in the building awaiting distribution. It was never to recover, having sustained some damage in an attack one month previously. The disorder was not repressed and even reached the palace of Saint James, residence of the monarch-in-exile, where the chapel and the Benedictine convent of the Queen Mary of Modena were half-ruined. ${ }^{78}$

In other places the damage was not as severe. The necessary precautions having been taken, the harm done to the altars of the French ambassador's residence in Saint James's Square and the Venetian embassy was limited. According to the account of the Tuscan envoy, the arrival of the owner of these residences, an English Protestant, and the presence of soldiers and some cavalry responsible of their protection mitigated the effects of these assaults. Another cautious planner, the Count of Sussex, was the owner of the nuncio's house. He had gone as far as to 'place two cannon in the front doorway' to protect it from attack. $^{79}$

The elimination of Catholic buildings and Jacobite symbols not only limited the political capital of the monarchy. The attacks were reproduced progressively through England, as was the defection of allegiance of officials, soldiers and nobles to the new regime from the House of Stuart. As rioting spread, the spaces destined to Catholic worship and houses across the kingdom became centres of popular agitation. ${ }^{80}$ Across the country levels of intensity and hostility were similar to those seen in London. One source stated that 'from York, Bristol, Cambridge where the Catholic chapels have been burnt, and the ornaments mistreated'. ${ }^{81}$ Oxford also saw similar anti-Catholic protests, as did other cities as far as Scotland (Pincus, 2013: 446-452).

In order to accentuate the gravity of disturbances and their territorial expansion, one author describes the English violence in a stereotyped way. In one of his letters, the Florentine representative Terriesi noted how 'such cruelty was followed by masons, carpenters armed with their tools to build and demolish houses, from soldiers, 
servants, coachmen, shopkeepers and the rabble'. ${ }^{82}$ This stratification was expressed in the breadth of the concepts 'rabble' or 'mob', common terms used to describe the agitators. It transmitted the idea of general discontent among Englishmen of a low social condition (Pincus, 2013: 451-454). Although the crowd made public their opposition to the Jacobite model of government and demonstrated their apparent religious prejudices through violence, 'this sort of thing is not carried out without there being some superior minds who order it' ${ }^{83}$ In consideration of the detrimental consequences that the popular violence caused to his house, Terriese held that

\begin{abstract}
'The murderous acts committed against the foreign ministers were an affront to the laws of the kingdom and the customs of hospitality; they were also an outrage against the rights of men and of God himself. They were committed on account of the encouragement, consensus and applause of great men and of those men who were in authority and whose offices obliged them to suppress disorders and to administer justice. All of these agreed to uproot Catholicism and they did not know how to achieve this in a more civil way'. ${ }^{84}$
\end{abstract}

The origins of this political agitation were not thought to lie in the seditious crowd; rather their true cause - and meaning - was found higher in the social and political hierarchy. They were rooted in the passive obedience of those sectors of the Protestant elite, including certain Catholic circles, critics with the court and supporters of the change in government that the revolution of 1688 brought about. ${ }^{85}$

News of the events of 11 December quickly circulated around Europe, emphasizing the violence exercised against the Spanish chapel and the high material losses. In The Hague, Manuel Coloma expressed his surprise at such an unexpected accident, being mindful of the respect that the English usually showed towards buildings of this sort. ${ }^{86}$ Waiting confirmation from Pedro Ronquillo, he estimated how, in a complex conjuncture, the information would exceed the truthful. ${ }^{87}$ Early in 1689 Manuel de la Guerra received letters in Bilbao from France (these did not come from his brother Felipe, Spanish consul in London), that reported the assault on Ronquillo's house. In notices of this sort genuine news was mixed up with many colourful rumours, hearsay and unsubstantiated information, thus providing only a partial version of events in London. The losses were estimated at more than two million escudos, an extraordinary figure that Guerra took to be exaggerated. Amongst these accounts were dispatches that in the course of the tumults they 'have killed or caused the death of many members of the family of our ambassador and the chaplain had his throat cut in the chapel of the residence, being dressed to say Mass' ${ }^{88}$ Both assertions were refuted a week later. This propaganda presenting the revolution as an anti-Catholic revolt covered up its true political nature: it also contributed to create the antipathy towards the English Protestant tradition that would spread across the continent in the following years. ${ }^{89}$
Amongst the numerous causes of this multifaceted and violent phenomenon, the confessional element was also noticed by Pedro Ronquillo to explain this new insult against his chapel and dignity. In an account of the incident written to the Marquis of Balbases, he explained how the contempt was motivated

'more by the hatred of religion than by any other pretext that they wanted to weigh up, in regards to the rabble when it began its tumult shouted and said that they were coming not to the residence of the ambassador of Spain but to the home of the Masses' (Rodríguez Villa, 1875: 308). ${ }^{90}$

In the previous years, and during the short-term closure of many other chapels in the kingdom, the chapel of Spain had strengthened its status as an active bastion of Catholicism and a central reference point for the royal mission to England. Looking in detail at the evolution of the incidents and the causes of these violent disruptions or shocks, it is clear that a number of ancillary factors must be included in any explanation of the eventual destruction of that center of religious power. While the confessional background cannot be dismissed, it is clear that the political component was also of great importance and influence.

At a number of moments Ronquillo had, of course, expressed his discomfort with the government of James II. Despite his more favorable attitude towards William of Orange being widely known at court, his house and chapel retained the old ornaments that had previously belonged to royal chapel, which had been closed several days before the flight of the King. Also proudly displayed were objects of great value that had been possessions of the Stuart king's supporters, among them the Franciscans (Lamberty, 1702, I: 660). The level of wealth accumulated in the Wild House thanks to these acquisitions, the treasures owned by the minister himself and the fabulous ornaments and sumptuous possessions gathered in one of the most decorated chapels of the city, served to identify it as an obvious target for the plundering crowd.

In regards to the economic motive of the mobs, the Dutch envoy Arnould van Citters argued that one of the main causes was the size of the ambassador's debts, Ronquillo being famous for his many promises and constant hardship. Despite his insistent petitions for financial assistance to Madrid, his inability to cover his expenditure as minister and support so luxurious a chapel led him to borrow successively from local moneylenders. The multiple postponements of payment led the unhappy creditors to 'revenge themselves in this manner', collecting debts by seizing the precious goods in the chapel. ${ }^{91}$

In contrast to the insult following the successful seizure of Buda, the attacks over several days in 1688 totally destroyed the Spanish religious building. Constructed by the crown with a specific political and religious purpose, the chapel had retained its strength in spite of the accidents, incidents and altercations that occurred suddenly in and around it. However, the last assault saw this royal 
symbol finally ruined and the political consequences of this misfortune transcended the material losses, significant though they may have been. On this night the crowd not only cast into the dark the confessional splendor of the monarchy of Carlos II, it also violated the custom of diplomatic immunity and committed a serious offence against the royal representation. With this act, the Catholic faithful were deprived of one of their principal places of worship. The Spanish chapel had been configured as symbolic space of the Mission to England, and so articulated the elaborate courtly ceremony and the ministry of the Word around a Baroque aesthetic. One other consequence was that Spanish diplomacy found one of its methods of intervention in court circles undermined. Previously, the chapel of Ronquillo had constituted an active social center for British elites loyal to or friendly towards the Catholic cause. It orbited around the person of the Queen Dowager and was linked spatially and politically to Somerset House.

The flight of James II left Catholic chapels across England in turmoil. Unable to return to Wild House, Pedro Ronquillo and his large family spent that bonfire-lit December night searching for security and wandering through a number of neighborhoods in the city. Catherine of Braganza was unwilling to accommodate them in her royal palace, as she wanted to avoid any prospective disturbance that might affect her or her official residence. Notified of the course of events and the deplorable state of the embassy, the council established by the temporary government sent its master of ceremonies to search for the Spanish diplomat (Rodríguez Villa, 1875: 308). The lords subsequently welcomed him with a display of public courtesy in Whitehall, receiving him in the suite previously occupied by the Duke of York, and he was assisted 'as a royal person' by the lord chamberlain of James II, the Count of Mulgrave (Macaulay, 1858, II: 341; Sheffield, 1723: 71; Ochoa Brun, 2006, VIII: 122). ${ }^{92}$

The day of the departure of the King saw the calling of the Convention Parliament. It was presided over by the Marquis of Halifax and composed of a number of English lords, both spiritual and temporal. The decision to convene it was made at an improvised meeting of that very evening, being present in it a number of Protestant bishops, some 'commoners of the kingdom' who found themselves in London, the mayor and a handful of aldermen (Beddard, 1988b). Considering the magnitude of the events and the degree of general public disorder, one of its first resolutions was to request of the Prince of Orange that he present himself at court. They thought that his presence would serve to calm the situation. The magistrates of London had not been able to control the situation: no sooner had they contained a fire and directed troops to extinguish it, than they found that the flames were quickly rekindled from the smoking embers. ${ }^{93}$

With the popular fervour continuing, confusion reigned at court. James II had fled to France; William of Orange was in political limbo and the ambassador Ronquillo remained in London without knowing how to present himself before the Dutch Prince, either as minister or as volunteer (Troost, 2005: 205-207). ${ }^{94}$ Given the unknowns within this process of political transition, the Spanish diplomat began to claim satisfaction for the damages he had received against his person and his honour 'so that a memory of this insult should be preserved'. Despite it not being the only chapel to be attacked, it had suffered the greatest harm. The inadequacy of the initial offer of reparation led the minister to request the return of all the stolen or confiscated goods, valued at more than one million reales de a ocho, and the re-construction of Wild House or another residence where he could re-establish Spanish representation at the British court (Bohun, 1689). ${ }^{95}$ In order to speed up this process with the Orangeist authorities, and to secure some sort of punishment of the agitators, the ambassador expected that Carlos II would impound or arrest English vessels and merchandise in Spanish ports. By use of a sort of trade embargo, he wanted to press the new government on its weak point. ${ }^{96}$ However, the Spanish Council of State opposed this kind of reprisal, which it took to be a drastic measure and not fitting to relations with an ally. In its deliberation, its members argued that the popular actions of 1688 were not sanctioned by the London government and, therefore, that 'there is no human judgement that can advice us to adopt such a remedy' (Maura Gamazo, 1951, I: 34-37). ${ }^{97}$

Given the gravity of the matter and its prospective political implications, William of Orange made an early apology to Carlos II for not preventing the insult against the ambassador, explaining that he had not been in London when the riot took place. In order to preserve good relations with Spain, he committed to make good the losses, compensating Ronquillo with whatever 'might be possible'. ${ }^{98}$ Together with a letter on this matter, the King's personal minister at the Madrid court, François de Schonenberg, announced the decision of the General States to send two deputies to England to deal with the reparations for the insult made against Wild House. ${ }^{99}$

Not content with promises of this sort, the minister found that he was hardly compensated for the public injury, his unfortunate position leading to a progressive increase in his debts. Devoid of all his possessions and living in some fear of his creditors, the ambassador also found that he was without any royal assistance. Moreover he felt aggrieved on account of the public nature of the injury he had suffered and the failure of Carlos II's government to adopt measures against British traders in Spain. ${ }^{100}$ Despite everything, and receiving neither the promised apology nor the two thousand doubloons which the Catholic King had decided to send to help him, he tried to preserve the decorum and the image of royal magnificence in the public functions. This was the case in the acts celebrating the memory of Queen Mary Louise of Orleans or the visit to London of Count Mansfelt, who was commissioned to celebrate the marriage by proxy of the Spanish monarch and Mariana of Neuburg (Maura Gamazo, 1951, I: 48-51). ${ }^{101}$

While London continued to debate the lawfulness of new Orangeist government, the destiny of the Jacobite rights to the throne and the role of Mary Stuart as de facto 
Queen, things were moving apace in Ireland, where the future of the English monarchy was settled by force of arms. Such weighty political matters inevitably overshadowed the Spanish representative's demands for redress (Hoppit, 2000: 19-23). ${ }^{102}$ Only after the enthronement of William III and Mary were the bilateral negotiations resumed, with the minister following to the letter the new instructions sent from Madrid. ${ }^{103}$ The orders of Carlos II insisted that Pedro Ronquillo should take care to moderate his behaviour and regulate his petitions and requests to the new King of Great Britain. He should only attempt to reclaim his jewels and those of his domestic servants, the chapel ornaments and liturgical objects. ${ }^{104}$ Prioritising reason of State and the maintenance of the alliance against France, the issue of compensation was finally resolved in Parliament, which gave the ambassador liberty to set the price of the losses caused by the infamous insult. He initially claimed damages of some $£ 50,000$, but eventually agreed to reduce this to $£ 20,000$, the bare minimum with which to pay off debts and restore his residence and chapel. ${ }^{105}$ In September, this sum was duly transferred to satisfy the dignity of the diplomat's person and the authority of Carlos II. ${ }^{106} £ 15,000$, 'as a one off gift' set in royal consignations, was the amount of compensation that William III finally paid to Pedro Ronquillo. ${ }^{107}$ This donation was the final redress for the insult to the Spanish embassy. With it the diplomat was able to begin construction of a new altar upon the ruins of the old one.

\section{CONCLUSIONS}

The proliferation of Catholic cult spaces during the reign of James II went hand in hand with the multiplication of violent incidents around them. This was nothing new in England. Throughout the $17^{\text {th }}$ century, isolated altercations took place in the diplomatic chapels in London. However, between 1685 and 1688, these individual cases gave way to a much more widespread phenomenon. The king's policy of re-catholicising the kingdom was met with the resistance of the protestant groups. Buildings used for the Catholics practises were understood as spaces of confrontation that left no room for negotiation, coexistence and tolerance. The traditional religious disagreement was compounded by political opposition to the king's decisions. The mob that ostensibly initiated these incidents, which were anything but spontaneous, was encouraged by the inactivity, if not the encouragement or even the direction, of the gentry.

The chapels thus emerged as a common, prominent target. Tension increased and popular anger flared up more and more often. Religious and political resistance took different shapes. Protest slogans and public mockery of Catholic practices gave way to intimidation and aggression, sometimes even in contempt of diplomatic immunity. The soldiers managed to contain the situation for a while, but it soon became unsustainable. Public discontent resulted in increasingly violent episodes, until on 11 December 1688, with the beginning of the Revolution, most chapels were subject to attacks of varying severity. The Spanish embassy, which had been the target of insults before, as during the celebrations for the take of Buda, was razed completely. The violent outburst against the embassy was explained in terms of anti-Catholic feelings, political quarrels and economic debts. William of Orange was left with no alternative but to shoulder the expense of the damages caused by his new vassals.

The exile of James II was the closing episode of England's last Catholic reign, and the attack on the Catholic chapels could well be seen as a damnatio memoriae on local Catholicism. For the Spanish monarchy, the loss of this Catholic stronghold in the north was a heavy political blow, which Ronquillo tried to offset by diplomatic means. A new altar dedicated to the 'Spanish religion' was built in London, but in the new political context this altar never acquired the social dimension of the old one. It was the beginning of a new period in the Spanish confessional diplomacy.

\section{ACKNOWLEDGEMENT}

This study has been undertaken within the framework of the programme Juan de la Cierva-Formación (FJCI2014-21225) and the projects of the Dirección General de Investigación del Ministerio de Economía y Competitividad, El modelo policéntrico de soberanía compartida (siglos XVI-XVIII): una vía alternativa a la construcción del Estado moderno (HAR2013-45357-P) y Sociedad cortesana y redes diplomáticas: la proyección europea de la monarquía de España (1659-1725) (HAR201567069-P). This work is part of Bravo Lozano (2014: 285311). I must thank Phillip Williams for his English translation of this paper.

\section{NOTES}

1 Archives Générales du Royaume de Belgique, Brussels [AGRB], Ambassade d'Espagne à La Hague, 481/2, f. 568v. The Count of Molina to Esteban de Gamarra. London, 23 May 1671.

2 John Miller has identified this politics as a missionary effort led by the King and seconded by different regular orders and the Society of Jesus, as well as by European ministers.

3 Although the aim of study is the chapels of London, this movement did not circumscribe only to the city. Along the kingdom of England were erected altars for the Catholic faithful.

4 The General Assembly of secular English clergy's resolution was 21 April 1687

5 Archivio Segreto Vaticano, Vatican City [ASV], Segreteria di Stato. Inghilterra, 12, f. 185v. Ferdinando d'Adda to Alderano Cybo. Windsor, 1 August 1687.

6 ASV, Segreteria di Stato. Inghilterra, 13, f. 17r. Ferdinando d'Adda to Alderano Cybo. London, 16 January 1688.

7 ASV, Segreteria di Stato. Inghilterra, 13, ff. 13r-14r. Ferdinando d'Adda to Alderano Cybo. London, 16 January 1688. This chapel was opened on 20 February 1688.

8 Archivo General de Simancas, Simancas [AGS], Estado, legajo 3961. Pedro Ronquillo to Carlos II. London, 11 November 1686 .

9 Archivo Histórico Nacional, Madrid [AHN], Estado, L. 183. Pedro Ronquillo to the Marquis of Villagarcía. London, 8 June 1687. 
10 ASV, Segreteria di Stato. Inghilterra, 17, ff. 23rv. Dispatch of the secretary of Pontifical State to Ferdinando d'Adda. London, 23 March 1686.

11 ASV, Segreteria di Stato. Inghilterra, 11, ff. 35v-36r. Ferdinando d'Adda to Alderano Cybo. London, 22 February 1686.

12 ASV, Segreteria di Stato. Inghilterra, 17, ff. 23rv. Dispatch of the secretary of Pontifical State to Ferdinando d'Adda. London, 23 March 1686; and Archivo Histórico de la Nobleza, Toledo [AHNOB], Osuna, CT. 62, D. 70. Felipe de la Guerra to the Duke of Infantado. London, 9 June 1686. In the precedent letter, Adda wanted to know the chaplains number of his chapel, 'considering the good that it will do'. ASV, Segreteria di Stato. Inghilterra, 11, f. 32v. Ferdinando d'Adda to Alderano Cybo. London, 18 February 1686. Allowing to the Lombard the decision of three or four chaplains, he opted for this last option 'for it to be the greatest number, it appearing to me to be the best service and decency of the said chapel'. ASV, Segreteria di Stato. Inghilterra, 11, f. 102v. Ferdinando d'Adda to Alderano Cybo. London, 10 May 1686. One of them was envied expressly from Rome, while the elected by Adda, the Irish Franciscan Bernard Gavan, was discharged to go to the missions of his homeland "where he could do more good than in England'. ASV, Segreteria di Stato. Inghilterra, 11, ff. 145r-146v. Ferdinando d'Adda to Alderano Cybo. Windsor, 28 June 1686.

13 ASV, Segreteria di Stato. Inghilterra, 11, f. 114r. Ferdinando d'Adda to Alderano Cybo. London, 3 June 1686.

14 AHNOB, Osuna, CT. 62, D. 61. Felipe de la Guerra to the Duke of Infantado. London, 4 March 1686. 'He is now thinking about how to build a chapel in the City of London, meaning, in the very middle of the city, while the rest of them are in the neighbourhood near to the court, where there is the large number of Catholics, or alternatively it could be far from the City to assuage the merchants who wanted it like that'. ASV, Segreteria di Stato. Inghilterra, 11, f. 40r. Ferdinando d'Adda to Alderano Cybo. London, 8 March 1686. In 1688, 'the Jesuits took the possession of this building and the leadership of the chapel. Thus, they settled there to open another school for the youngsters in the middle of the city'. ASV, Segreteria di Stato. Inghilterra, 13, ff. $59 v-60$ r. Ferdinando d'Adda to Alderano Cybo. London, 26 March 1688.

15 In other, the minister adverted how 'a lot of people believe that [this chapel] is more a product of the churchmen who serve it than other cause, as they have to pay for it. It is true that the poor minister receives the benefit of a house for free, as well as a coach on account of the great distance to the royal palace and some money to clothe himself in decency; nevertheless, it is believed that [the chapel] will be very useful in that place'. AGS, Estado, legajo 3961. Pedro Ronquillo to Carlos II. London, 1 April 1686.

16 ASV, Segreteria di Stato. Inghilterra, 11, ff. 95v-96r. Ferdinando d'Adda to Alderano Cybo. London, 3 May 1686.

17 AGS, Estado, legajo 3961. Pedro Ronquillo to Carlos II. London, 1 April 1686.

18 This inversion of the ordinary process for construction was one of the causes that Felipe de la Guerra, Spanish consul in London, saw as a justification for the unilateral decision of the mayor. 'This has caused a sudden blaze, but the directors think it is well merited, as [representative from the Palatine] has got the wrong end of the stick. The diplomat should first have gone to live in the house and then thought about a chapel, but they have done it backwards and so things have happened in this way, and God only knows how this will end'. AHNOB, Osuna, CT. 62, D. 66. Felipe de la Guerra to the Duke of Infantado. London, 29 April 1686.

19 ASV, Segreteria di Stato. Inghilterra, 11, f. 82v. Ferdinando d'Adda to Alderano Cybo. London, 12 April 1686.

20 AGS, Estado, legajo 3961. Pedro Ronquillo to Carlos II. London, 15 April 1686; and AHNOB, Osuna, CT. 62, D. 66. Felipe de la Guerra to the Duke of Infantado. London, 29 April 1686.
21 AHN, Estado, L. 183. Pedro Ronquillo the Marquis of Villagarcía. London, 10 May 1686. 'Some have sought to exaggerate this greatly, but I can tell you that, until now, it is a thing that deserves neither mention, nor concern'. Idem. Pedro Ronquillo to the Marquis of Villagarcía. London, 3 May 1686.

22 AHN, Estado, L. 183. Pedro Ronquillo to the Marquis of Villagarcía. London, 17 May 1686.

23 The opening of the chapel happened on Sunday, 28 April 1686. ASV, Segreteria di Stato. Inghilterra, 11, ff. 95v-96r. Ferdinando d'Adda to Alderano Cybo. London, 3 May 1686. Il corriere ordinario, no. 40, Vienna: appresso Gio. van Ghelen, 1686. Notices. London, 29 April 1686; Recüeil des nouvelles ordinaries et extraordinaires, Paris: Du Bureau d'Adresse, 1687, p. 227. Notices. London, 2 May 1686.

24 ASV, Segreteria di Stato. Inghilterra, 11, ff. 114v-115r. Ferdinando d'Adda to Alderano Cybo. London, 3 June 1686.

25 AHN, Estado, L. 183. Pedro Ronquillo to the Marquis of Villagarcía. Windsor, 7 June 1686.

26 Il corriere ordinario informed regularly about these altercations along May and June. Il corriere ordinario, no. 42, 44, 50, 52, Vienna: appresso Gio. van Ghener, 1686. Notices. London, 6 and 13 May, and 4 and 10 June 1686, respectively.

27 AHNOB, Osuna, CT. 62, D. 68 and 70. Felipe de la Guerra to the Duke of Infantado. London, 27 May and 9 June 1686. Biblioteca Nazionale di Napoli, Naple [BNNa], Sezione Napoletana, Periodici, 120. Gazzetta di Napoli, no. 5. Naples: appresso Domenico Antonio Parrino, 1686. Notices of London, 17 May 1686

28 AHNOB, Osuna, CT. 62, D. 67. Felipe de la Guerra to the Duke of Infantado. London, 13 May 1686.

29 AGS, Estado, legajo 3961. Pedro Ronquillo to Carlos II. London, 27 May 1686; and AHN, Estado, L. 183. Pedro Ronquillo to the Marquis of Villagarcía. London, 31 May 1686.

30 AHNOB, Osuna, CT. 62, D. 70. Felipe de la Guerra to the Duke of Infantado. London, 9 June 1686.

31 'To show you in how little time we knew of this event, the extraordinary report of it arrived here in just 9 days. This shows a good diligence'. AHNOB, Osuna, CT. 62, D. 78. Felipe de la Guerra to the Duke of Infantado. London, 16 September 1686. Archivio di Stato di Modena, Modena [ASMo], Ambasciatori, Inghilterra, busta 5. The Marquis Giovanni Francesco Cattaneo to the Duke of Modena. London, 13 September 1686.

32 AHN, Estado, L. 183, s. fol. Pedro Ronquillo to the Marquis of Villagarcía. Windsor, 13 September 1686. Such was the royal happiness that Felipe de la Guerra wrote to the Duke of Infantado: 'Blessed be God for all. I can inform Your Excellence that they have assured me that this good King cried with joy with our ambassador who recounted the news to him and [His Majesty] said that it simply could not come at a better moment'. AHNOB, Osuna, CT. 62, D. 78. Felipe de la Guerra to the Duke of Infantado. London, 16 September 1686.

33 ASV, Segr. St. Inghilterra, 11, f. 193r. Ferdinando d'Adda to Alderano Cybo. Windsor, 13 September 1686.

34 AHN, Estado, L. 183, s. fol. Pedro Ronquillo to the Marquis of Villagarcía. Windsor, 13 September 1686. ASV, Segreteria di Stato. Fiandra, 76, f. 542r. Notices. Brussels, 4 October 1686.

35 James II and Mary of Modena returned from Windsor the eve of the London celebrations. ASV, Segreteria di Stato. Inghilterra, 11, f. 197r. Ferdinando d'Adda to Alderano Cybo. London, 20 September 1686.

36 London: Charles Bill, Henry Hills and Thomas Newcomb, 1686. BNNa, Sezione Napoletana, Periodici, 120. Gazzetta di Napoli, no. 23. Naples: appresso Domenico Antonio Parrino, 1686. Notices. London, 20 September 1686; and Recüeil des nouvelles ordinaires et extraordinaires, Paris: du Bureau d'Adresse, 1687, p. 539. Notices. London, 23 September 1686. It is notable how in The London Gazette did not do mention through September and October on the religious celebrations organized by James II, despite Thomas Newcomb was one of the printers of the prayer. 
37 The date of the prayer is 12 September 1686 in English style. It corresponds with Sunday 22 in the Gregorian calendar

38 The Modena representative in England, Giacomo Ronchi, shared this sensation "with the best music of this kingdom, the pontifical Mass and the Te Deum for thanksgiving the taken of Buda [was celebrated], with their Majesties in attendance at this solemn function, the like of which has not ever been seen in this kingdom since the schism. It was great for all of the Catholics and Protestants alike'. ASMo, Ambasciatori, Inghilterra, busta 4. Giacomo Ronchi to the Duke of Modena. London, 28 September 1686. Afterwards, the Duke of Montalto set out his admiration for James II: he is 'most deserving of the greatest applause and in [this] it has become clear what a great Catholic he is and how grateful we Catholics should be towards him'. Cfr. Colección de documentos inéditos para la Historia de España [CODOIN], (1882, LXXIX: 371). The Duke of Montalto to Pedro Ronquillo. Madrid, 7 November 1686.

39 AHN, Estado, L. 183, s. fol. Pedro Ronquillo to the Marquis of Villagarcía. Windsor, 13 September and London, 20 September 1686.

40 AHN, Estado, L. 183, s. fol. Pedro Ronquillo to the Marquis of Villagarcía. Windsor, 20 September 1686.

41 Ibidem.

42 AHN, Estado, L. 183, s. fol. Pedro Ronquillo to the Marquis of Villagarcía. Windsor, 13 September 1686; and Archivio di Stato di Firenze, Florence [ASF], Mediceo del Principato, filza 4213. Notices. London, 23 September 1686.

43 ASF, Mediceo del Principato, filza 4213. Notices. London, 23 September 1686.

44 BNNa, Sezione Napoletana, Periodici, 120. Gazzetta di Napoli, no. 23. Naples: appresso Domenico Antonio Parrino, 1686. Notices. London, 20 September 1686.

45 ASF, Mediceo del Principato, filza 4213. Notices. London, 23 September 1686.

46 'The Spanish Ambassador made a bonfire at Wild House last night and brought out wine for the mob'. J. D. Colt to Robert Harley. Brampton, 9/19 September 1686, Historical Manuscripts Commission, The manuscripts of his grace the Duke of Portland, preserved at Welbeck Abbey (1894). Eyre and Spottiswoode, London, vol. III, p. 397; and BNNa, Sezione Napoletana, Periodici, 120. Gazzetta di Napoli, no. 23. Naples: appresso Domenico Antonio Parrino, 1686. Notices. London, 20 September 1686.

47 In a letter of J. D. Colt to Robert Harley could be read how 'the rabble overthrew the bonfires, broke the cask of wine and broke the windows and pulled down some of the brick wall'. Brampton, 9/19 September 1686. HMC, Portland MSS, 397. Harris attributes, for confusion, the victory of Buda to the Spanish army, not to the Holy League.

48 The National Archives: Public Record Office, Kew [TNA: PRO], State Papers, 94/72, f. 95v. Pedro Ronquillo to the Count of Sunderland. London, 19 September 1686. The abbot Terriesi told to the Great Duke the insult against the house of Ronquillo, noted how 'because the common people publicly say that they would rather see Buda in the hands of the Devil than in those of the Catholics, and they feel for the Turkish defeat, without thinking of its advantages'. ASF, Mediceo del Principato, filza 4213. Notices. London, 23 September 1686.

49 Recüeil des nouvelles ordinaires et extraordinaires, Paris: du Bureau d'Adresse, 1687, p. 539. Notices. London, 23 September 1686.

50 In a letter of James II to his son-in-law, William of Orange, told him the events happened in the chapel of Ronquillo during the Buda celebrations. TNA: PRO, State Papers, $8 / 4$, no. 9. James II to William of Orange. Windsor, 10/20 September 1686 .

51 The Duke of Montalto lamented how 'the disrespect of the plebs was in part punished by Your Excellency having repeated the festivities and their not having burst out into disorder as on the first day'. CODOIN, LXXIX: 371. The Duke of Montalto to Pedro Ronquillo. Madrid, 7 November 1686. Howev- er, as noted Francesco Terriesi, the second night did not happen a new insult, as the crowd had planned, after seeing the guardians and 'the protections against them'. ASF, Mediceo del Principato, filza 4213. Notices. London, 23 September 1686.

52 This opinion was comparted by Ferdinando d'Adda who, in a letter to Cybo, exponed what happened in Ronquillo's chapel and he affirmed 'It is believed that this attack has been caused by the animosity against the [Habsburg] cause, with this demonstration being perhaps the work of the Presbyterians in particular, who are very discontent about the successes of the Christian arms against the Turks, especially as Buda had been under the domination of the Turks for a long time and has now been captured by the Catholics, for whom their hatred is greater and is even more intense than their hatred for the infidel'. ASV, Segreteria di Stato. Inghilterra, 11, ff. 199rv. London, 20 September 1686.

53 TNA: PRO, State Papers, 94/72, f. 95v. Pedro Ronquillo to the Count of Sunderland. London, 19 September 1686. The answer of the secretary of State to the Spanish ambassador could be found in TNA: PRO, State Papers, 104/187, p. 233. Windsor, 21 September 1686.

54 Terriesi explained to the Great Duke that he was worried about the insults against Wild House, lamenting the answer that the English justice offered in such circumstances and due to which the guilty parties went unpunishment 'in a country where the ius gentium has never been introduced, which would at least afford reciprocal treatment to the other [countries], and where they have never established laws to deal with the complaints of foreigners as they are dealt with [in foreign countries]'. Thus, he judged that the response to the throw of stones would have to be with the weapons. It was a satisfaction equally violent, although shared by some Ronquillo's guests before the mild penalties that suffered the thirty men arrested that night. ASF, Mediceo del Principato, filza 4213. Notices. London, 30 September 1686.

55 AGRB, Ambassade d'Espagne à La Hague, 496. Pedro Ronquillo to Manuel Coloma. Windsor, 15 August 1687; and AHNOB, Osuna, CT. 62, D. 105. Felipe de la Guerra to the Duke of Infantado. London, 17 August 1687.

56 AHNOB, Osuna, CT. 62, D. 68. Felipe de la Guerra to the Duke of Infantado. London, 27 May 1686.

57 ASV, Segreteria di Stato. Inghilterra, 13, f. 43v. Ferdinando d'Adda to Alderano Cybo. London, 7 March 1688. AGS, Estado, legajo 3961. Consult of the council of State. Madrid, 27 June 1686

58 These events were explained by the internuncio Tanara, who stated that a significant number of publications were beginning to circulate 'against the majesty of the King, and all tend to incite revolution in the kingdoms of Great Britain and to place in doubt the birth of the Prince of Wales'. ASV, Segreteria di Stato. Fiandra, 78, ff. 646rv y 681v. Sebastiano Antonio Tanara to Alderano Cybo. Brussels, 5 and 19 November 1688 .

59 AGS, Estado, legajo 3971. Castilian translation of William of Orange declaration before his journey to England. The Hague, 10 October 1688.

60 Biblioteca Francisco Zabálburu, Madrid [BFZ], Fondo Altamira, caja 265, GD 1. Pedro Ronquillo to the Marquis of Cogolludo. London, 8 October 1688.

61 BFZ, Fondo Altamira, caja 265, GD 1. Pedro Ronquillo to the Marquis of Cogolludo. London, 22 October 1688. In his answer, the Castilian aristocrat coincided with the impression of English misgovernment due to the control exerted by the Jesuits in the monarchy designs. BFZ, Fondo Altamira, caja 265, GD 1. The Marquis of Cogolludo to Pedro Ronquillo. Rome, 27 November 1688.

62 ASMo, Ambasciatori, Inghilterra, busta 6. The abbot Gaspare Rizzini to the Duke of Modena. London, 21 October 1688; and ASMo, Ambasciatori, Inghilterra, busta 4 . The agent Giacomo Ronchi to the Duke of Modena. London, 22 October 1688 . 
63 In one of his letters, John Ellis told about the demolition of the 'Mass-house' in Lime Street and burning all the altar implements.

64 ASV, Segreteria di Stato. Inghilterra, 13, ff. 267r-268r. Ferdinando d'Adda to Alderano Cybo. London, 22 October 1688; TNA: PRO, State Papers, 31/4, ff. 135Arv. The Duke of Norfolk to the Count of Sunderland. London, 25 October 1688.

65 BFZ, Fondo Altamira, caja 265, GD 1. Pedro Ronquillo to the Marquis of Cogolludo. London, s. f., October 1688.

66 The nuncio Adda told how 'it is felt in some parts of the kingdom that the crowds are committing insults against the Catholic clergy and chapels, there already being present across the kingdom a presumption of being able to commit acts of evil with impunity, and although all [existing] orders serve as a basis for action against the transgressors, it is clear that the authorities would rather protect the iniquity than punish it'. ASV, Segreteria di Stato. Inghilterra, 13, ff. 287rv. Ferdinando d'Adda to Alderano Cybo. London, 5 November 1688.

67 ASMo, Ambasciatori, Inghilterra, 6. The abbot Gaspare Rizzini to the Duke of Modena. London, 11 November 1688.

68 BFZ, Fondo Altamira, caja 265, GD 1. Pedro Ronquillo to the Marquis of Cogolludo. London, 8 November 1688. 'They were committing all possible insults, carrying what wood remained to them and making of it a triumph and a sacrifice to their fury'. ASV, Segreteria di Stato. Inghilterra, 13, f. 291v. Ferdinando d'Adda to Alderano Cybo. London, 12 November 1688 .

69 ASV, Segreteria di Stato. Inghilterra, 13, ff. 295v-296r. Ferdinando d'Adda to Alderano Cybo. London, 15 November 1688 .

70 ASV, Segreteria di Stato. Inghilterra, 13, ff. 339r-340v. Ferdinando d'Adda to Alderano Cybo. London, 26 November 1688 .

71 ASV, Segreteria di Stato. Inghilterra, 13, f. 341v. Ferdinando d'Adda to Alderano Cybo. London, 26 November 1688.

72 In the functions of Elizabethan anniversary of 1688 finally the image of the Pope did neither burn, nor the nuncio who 'also had to enter in the bonfire'. AGS, Estado, legajo 3963. Account of the state of the England matters, from 22 November to 6 December. Madrid, 31 December 1688.

73 AHN, Estado, L. 183. Pedro Ronquillo to the Marquis of Villagarcía. London, 17 December 1688.

74 British Library, London [BL], Egerton Manuscripts 2717, f. 415r. Newsletters from London. London, 11 December 1688.

75 ASF, Mediceo del Principato, filza 4246, doc. 425. Francesco Terriesi to Apollonio Basetti. London, 31 December 1688; and AGRB, Ambassade d'Espagne à La Hague, 496. Pedro Ronquillo to Manuel Coloma. London, 13 December 1688. This letter also was sent to the Marquis of Villagarcía. AHN, Estado, L. 183.

76 With this milieu of destruction, to Pedro Ronquillo served himself 'with only the consolation of having had the chance to consume the Most Holy Eucharist', as well as 'the circumstances that occurred, miraculously, on account of he and his family not having appeared at that moment'. AGS, Estado, legajo 8342, f. 379. Consult of the council of State. Madrid, 29 January 1689.

77 ASF, Mediceo del Principato, filza 4246, doc. 424. Francesco Terriesi to Apollonio Bassetti. London, 24 December 1688. John Aubrey included among this documents, manuscripts and antiques of incalculable value. Some pieces were unique in the world and the Imperial resident Hoffmann calculated the losses in five hundred thousand escudos.

78 ASF, Mediceo del Principato, filza 4241. Francesco Terriesi to Apollonio Bassetti. London, 27 December 1688. See Beddard (1988a: 39).

79 ASF, Mediceo del Principato, filza 4246, doc. 424. Francesco Terriesi to Apollonio Bassetti. London, 24 December 1688. See Lamberty, (1702, I: 662). Paolo Sarotti was the Venetian resident in London.

80 ASV, Segreteria di Stato. Inghilterra, 13, f. 373r. Ferdinando d'Adda to Alderano Cybo. London, 17 Dcember 1688. Pedro
Ronquillo described to the Marquis of Villagarcía his situation in England after the arrival of William of Orange in this terms: 'the agitators ruin the chapels of the kingdom, sack the houses of Catholics and arrest the priests'. AHN, Estado, L. 183. Pedro Ronquillo to the Marquis of Villagarcía. London, 18 December 1688.

81 ASV, Segreteria di Stato. Firenze, 77, f. 8r. Francesco Terriesi to Alderano Cybo. London, 16 December 1688.

82 ASF, Mediceo del Principato, filza 4246, doc. 424. Francesco Terriesi to Apollonio Bassetti. London, 24 December 1688.

83 AHNOB, Osuna, CT. 63, D. 3. Manuel de la Guerra to the Duke of Infantado. Bilbao, 21 January 1689.

84 ASF, Mediceo del Principato, filza 4246. Francesco Terriesi to Cosimo III. London, 3 January 1689.

85 ASV, Segreteria di Stato. Inghilterra, 13, f. 340v. Ferdinando d'Adda to Alderano Cybo. London, 26 November 1688.

86 AGRB, Ambassade d'Espagne à La Hague, 496. Manuel Coloma to Pedro Ronquillo. The Hague, 28 December 1688 and 7 January 1689.

87 AHN, Estado, L. 181. Manuel Coloma to the Marquis of Villagarcía. The Hague, 30 December 1688.

88 AHNOB, Osuna, CT. 63, D. 3. Manuel de la Guerra to the Duke of Infantado. Bilbao, 21 January 1689.

89 AHNOB, Osuna, CT. 63, D. 3. Manuel de la Guerra to the Duke of Infantado. Bilbao, 28 January 1689.

90 Pedro Ronquillo to the Marquis of Los Balbases. Whitehall, 24 December 1688.

91 Algemen Rijkarchief, The Hague [ARA], Staten-Generaal, Inv. 5915. Arnould Van Citters to General States. Westminster, 24 December 1688. See Macaulay (1858, II: 340-341).

92 AGS, Estado, legajo 8342, f. 379. Consult of the Council of State. Madrid, 29 January 1689.

93 AHN, Estado, L. 183. Pedro Ronquillo to the Marquis of Villagarcía. London, s. f., December 1688.

94 AGS, Estado, legajo 8342, f. 368. Consult of the Council of State. Madrid, 23 December 1688.

95 On 13 December 1688, The London Gazette published a requirement on the stolen objects in the house and chapel of Pedro Ronquillo. Thus, 'if any person shall discover any of the said plate, goods, goods, books or papers, and bring the same to the Council-Chamber in Whitehall or give such information that they may be recovered, they shall be very well rewarded in proportion to what shall be so recovered'.

96 'If the English do not recognise any half-heartedness in claiming satisfaction for these insults, then they will weaken and do what is just, as they only look to their own interests and their nature makes them changeable'. AGS, Estado, legajo 8342, f. 379. Consult of the Council of State. Madrid, 29 January 1689. Before the damages that suffered the house of Florentine Terriesi, in London was rumoured how his lord, the Great Duke of Tuscan, Cosimo III, would adopt the same position of that proposed Pedro Ronquillo: block the commerce of English merchants that operated in the open port of Livorno. ASF, Mediceo del Principato, filza 4246, doc. 98. Francesco Terriesi to Cosimo III. London, 27 December 1688.

97 AGS, Estado, legajo 8342, f. 379. Consult of the Council of State. Madrid, 29 January 1689

98 Real Academia de la Historia, Madrid [RAH], Salazar y Castro, 9/667. William of Orange to Carlos II. Saint James, 23 January 1689.

99 A short time afterwards, he sent Manuel Coloma instructions to present a complaint to the Estates General that 'without delay they take all measure to rebuild the chapel and house of my ambassadors, so that they can reside in London, as they have done until now, and that just satisfaction be given to the cost of what was lost, both to don Pedro [Ronquillo] and to those who had a stake in it having deposited their belongings in the house of this minister'. AGS, Estado, legajo 3913. Dispatch of Carlos II to Manuel Coloma. Madrid, 10 February 1689.

100 Pedro Ronquillo emphasised how the royal refusal to take commercial reprisals against English merchants in Spain 
had meant that "they have lost the fear that previously brought them to see reason and they say now that they may find it hard to give compensation to an ambassador when it appears that his King does not want this to happen'. AGS, Estado, legajo 8342, f. 395. Pedro Ronquillo to Carlos II. London, 14 March 1689.

101 AGS, Estado, legajo 8342. Consults of the Council of State. Madrid, 18 March and 25 June 1689; and AGRB, Secrétairerie d'Etat et de Guerre, 607. Pedro Ronquillo to Carlos II. London, 15 August 1689.

102 Similar was the case of the Florentine Terriesi. Despite the comparison of the damages suffered in his house with the losses of Ronquillo, his level of satisfaction was lower. To understand this process, parallel to the Spanish complaint, see the correspondence of Francesco Terriesi with Cosimo III and Apollonio Bassetti at the beginning of 1689 . It can be found in ASF, Mediceo del Principato, filza 4246.

103 TNA: PRO, State Papers, 45/13, f. 14.

104 AHN, Estado, legajo 2787, exp. 22. Instructions to Pedro Ronquillo with motive of the royal exaltation of William III. Madrid, s. f., May 1689.

105 The economic proposals of the Spanish minister were given to the new secretary of State, Count of Shrewsbury. In June 1689 , Pedro Ronquillo suggested the amount of $£ 30,000$, considering that his 'family, who were more than twenty-four persons that he supported, has lost everything'. AGRB, Secrétairerie d'Etat et de Guerre, 608. Pedro Ronquillo to the Count of Shrewsbury. London, 4 June 1689. At the end of this month, following the Carolinian instructions, he reduced the quantity until $£ 20,000$, although the English ministry would fix the definitive satisfaction in $£ 15,000$. AGRB, Secrétairerie d'Etat et de Guerre, 608. Pedro Ronquillo to the Count of Shrewsbury. London, 30 June 1689.

106 AGRB, Secrétairerie d'Etat et de Guerre, 608. Pedro Ronquillo to Carlos II. London, 10 October 1689

107 AGS, Estado, legajo 3964. Pedro Ronquillo to Carlos II. London, 26 September 1689.

\section{REFERENCES}

Álvarez-Ossorio Alvariño, Antonio (2001) Milán y el legado de Felipe II. Sociedad Estatal para la Conmemoración de los Centenarios de Felipe II y Carlos V, Madrid.

Beddard, Robert (1988a) "Anti-popery and the London Mob, 1688". History Today, 38: 36-39.

Beddard, Robert (1988b) A Kingdom without a King: The Journal of the Provisional Government in the Revolution of 1688. Phaidon, London.

Bohun, Edmund (1689) The history of the desertion or An account of all the public affairs in England, from the beginning of September 1688 to the Twelfth of February following. Richard Chiswell, London.

Bravo Lozano, Cristina (2014) Tierras de Misión. La politica confesional de la Monarquía de España en las Islas Británicas, 1660-1702. Unpublished PhD thesis. Universidad Autonoma de Madrid, Madrid.

Bravo Lozano, Cristina (2015) "Celebrando Buda. Fiestas áulicas y discurso político en las cortes de Madrid y London". In Visperas de Sucesión. Europa y la monarquía de Carlos II, edited by García García, Bernardo J. and Álvarez-Ossorio Alvariño, Antonio. Fundación Carlos de Amberes, Madrid: 351-374.

Bravo Lozano, Cristina (2016) "A berretta for the Nuncio. Roman diplomacy, court ceremony and royal favour in the Madrid of Charles II". In The transition in Europe between XVII ${ }^{\text {th }}$ and $X{ }^{\prime} I^{\text {th }}$ centuries, edited by Álvarez-Ossorio Alvariño, Antonio, Cremonini, Cinzia and Riva, Elena. FrancoAngeli, Milan: 115137.

Campana de Cavelli, marchioness (1871) Les dernier Stuart à Saint-Germain en Laye. Documents inédits et authentiques puisés aux archives publiques et privées. Librairie Académique, Didier \& Cie., Paris.
Carrafiello, Michael L. (1994) "English Catholicism and the Jesuit Mission of 1580-1581”. The Historical Journal, 37(4): 761774 .

Ellis, George Agar (editor) (1829) The Ellis Correspondence. Henry Colburn, London, vols. I-II.

Harris, Tim (1997) "The parties and the people". In The reigns of Charles II and James VII \& II, edited by Glassey, Lionel K. J. Macmillan, London: 125-151.

Harris, Tim and Taylor, Stephen (editors) (2013) The Final Crisis of the Stuart Monarchy: The Revolutions of 1688-91 in their British, Atlantic and European Contexts. Boydell, Woodbridge.

Herrero Sánchez, Manuel (2002) "La perduración de la cuestión irlandesa: un obstáculo en las relaciones anglo-españolas durante la segunda mitad del siglo XVII". In Irlanda y la Monarquía Hispánica: Kinsale, 1601-2001. Guerra, política, exilio y religión, edited by García Hernán, Enrique et al. Universidad de Alcalá-CSIC, Madrid: 401-422.

Hoak, Dale and Feingold, Mordechai (editors) (1996) The World of William and Mary. Anglo-Dutch Perspective on the Revolution of 1688-89. Stanford University Press, Stanford, California.

Holt, T. G. (1990) "A School in the Savoy, 1687-1688". Transactions of the London and Middlesex Archaeological Society, 41: 21-27.

Hoppit, Julian (2000) A land of liberty? England 1689-1727. Oxford University Press, Oxford.

Israel, Jonathan I. (editor) (2003) The Anglo-Dutch Moment: Essays on the Glorious Revolution and its World Impact. Cambridge University Press, Cambridge.

Jones, J. R. (1991) “James II's Revolution: royal policies, 16861692". In The Anglo-Dutch momento. Essays on the Glorious Revolution and its world impact, edited by Israel, Jonathan I. Cambridge University Press, Cambridge: 47-71.

Kaplan, Benjamin J. (2002) "Diplomacy and domestic devotion: embassy chapels and the toleration of religious dissent in Early Modern Europe". Journal of Early Modern History, 6 (4): 341361.

Lamberty, Guillaume de (1702) Mémoires de la dernière révolution d'Angleterre, tom. I. Chez les Frères l'Honoré. The Hague.

Leti, Gregorio (1685) Il cerimoniale historico e politico. Giovanni \& Egidio Janssonio a Waesberge, Amsterdam.

Levillain, Charles-Édouard (2010) Vaincre Louis XIV. Angleterre, Hollande, France. Histoire d'une relation triangulaire (16651688). Champ Vallon, Seyssel.

Macaulay, Thomas Babington (1858) The history of England from the accession of James II, vol. II. Longman, Brown, Green, Longmans and Roberts, London.

Macdonald, G. (1927) "The Lime Street Chapel" (parts I and II). Dublin Review, 180 and 181: 263-264 and 2-6, respectively.

Maura Gamazo, Gabriel (editor) (1951) Correspondencia entre dos embajadores. Don Pedro Ronquillo y el marqués de Cogolludo, 1689-1691, tom. I. Real Academia de la Historia, Madrid.

McCoog, Thomas M., SJ (1996) The Society of Jesus in Ireland, Scotland and England, 1541-1588. Brill, Leiden-New YorkKöln.

McCoog, Thomas M., SJ (2012) The Society of Jesus in Ireland, Scotland, and England, 1589-1597: Building the Faith of Saint Peter upon the King of Spain's Monarchy. Ashgate PublishingInstitutum Historicum Societatis Iesu, Burlington-Roma.

Miller, John (1997) The Glorious Revolution. Longman, London.

Miller, John (2000) James II. Yale University Press, New Haven.

Miller, John (2008) Popery \& politics in England, 1660-1688. Cambridge University Press, Cambridge.

Niggemann, Ulrich (2012) "Some Remarks on the Origins of the Term 'Glorious Revolution". The Seventeenth Century, XXVII (4): 477-487

Ochoa Brun, Miguel-Ángel (2006) Historia de la diplomacia española, vol. VIII. Ministerio de Asuntos Exteriores, Madrid.

Pincus, Steve (2006) "The European catholic context of the revolution of 1688-89. Gallicanism, Innocent XI, and catholic opposition". In Shaping the Stuart World, 1603-1714. The Atlantic Connection, edited by Macinnes, Allan I. and Williamson, Arthur. H. Brill, Leiden: 79-115. 
Pincus, Steve (2013) 1688, la primera revolución moderna. Acantilado, Barcelona.

Powell, Anthony (1988) John Aubrey and his friends. Eyre and Spottiswoode, London.

Raleigh Trimble, William (1946) "The Embassy Chapel Question, 1625-1660". The Journal of Modern History, 18(2): 97-107.

Rodríguez Villa, Antonio (1875) "Atentado cometido por el pueblo de London en 1688 contra la embajada española". Revista Europea, 96: 308-309.

Rowlands, Marie B. (1999) English Catholics of Parish and Town, 1558-1778. Catholic Record Society, London.

Sachse, William L. (1964) "The Mob and the Revolution of 1688", Journal of British Studies, 4(1): 23-40.

Speck, William Arthur (1989) Reluctant Revolutionaries. Englishmen and the Revolution of 1688. Oxford University Press, Oxford.

Sheffield, John (1723) Some account of the revolution, vol. 2. John Barber, London.
Troost, Wout (2005) William III, the Stadholder-King. A Political Biography. Ashgate, Aldershot.

Vivo, F. de (2012) "Public Sphere or Communication Triangle? Information and Politics in Early Modern Europe". In Beyond the Public Sphere. Opinions, Publics, Spaces in Early Modern Europe, edited by Rospocher, Massimo. Società editrice il Mulino-Buncker\&Humblot, Bologna-Berlin: 115-136.

Walsham, Alexandra (2003) "Miracles and the Counter-Reformation Mission to England". The Historical Journal, 46(4): 779815 .

Walter, John (2007) Crowds and popular politics in early modern England. Manchester University Press, Manchester.

Whitehead, Maurice (2009) "“Superior to the Rudest Shocks of Adversity'. English Jesuits Education and Culture in the Long Eighteenth Century, 1688-1832". In Educating the Child in Enlightenment Britain. Beliefs, Cultures, Practices, edited by Hilton, Mary and Shefrin, Jill. Ashgate, Farnham: 131-146. 